\title{
A View of the Political Environments of Implementing Literary Appreciation into Chinese Rural Senior High Schools
}

\author{
Take the Rural Senior High Schools of Shaanxi Province as an Example
}

\author{
Yingjie Guo \\ School of Foreign Languages \\ Shaanxi Normal University \\ 710062 Xi'an, China \\ guoyingjie@snnu.edu.cn
}

\author{
Qing Zhao \\ School of Foreign Languages \\ Xi'an University of Finance and Economics \\ 710100 Xi'an, China \\ bluehaddylight@163.com
}

\begin{abstract}
To have a view of the political environments of implementing literary appreciation into Chinese Rural Senior High Schools, the paper first relates to the definition of literary appreciation and interprets its importance for the philosophers and scholars at home and aboard. As for the role of literary appreciation in the rural Senior High Schools, the paper holds that "literary appreciation should be an important teaching activity". However, a field research about the rural middle schools and primary schools of Northern Shaanxi of China in 2010 makes us lost in thought. Through examining the themes like (1) Receiving quality-oriented education is both students' rights and their obligations, (2) The rural education is one of the fatal projects of revitalizing China in the long run, (3) Colorful and diversified course designing is demanded in national educational reform and development, (4) The rural Senior High Schools are available to improve the populace's cultivation and by referring to Chinese national laws and political documents like The Educational Law of the PRC(1995), Chinese Educational Revitalization Action Plan for the 21st Century(1998), The Decision of Deepening Chinese Education Reform and Promoting Comprehensively the Quality-oriented Education by the CPC Central Committee and the State Council(1999), The Decision on the Foundation Education Reform and Development of the State Council(2001), The Curriculum Scheme for the Senior High Schools (experimental manuscript)(2003), Law of Compulsory Education of the PRC(2006), etc., the paper suggests that Chinese people should be optimistic about the future of literary appreciation in rural Senior High Schools. Specifically, since a lot of educational laws and political documents are available and play their roles in concrete fields and provide good environments for the development of the rural Senior High Schools as well as the fulfillment of literary appreciation in the rural Senior High Schools, people should believe that Chinese rural Senior High Schools, together with the national rural education, will have a bright future. Meanwhile, fulfilling the literary appreciation in the rural Senior High Schools will be one of those rewarding experiences in the social life.
\end{abstract}

Keywords-political environments; rural Chinese Senior High School; literary appreciation

\section{INTRODUCTION}

Literary appreciation is a special literary activity that employs the literary texts or the relevant texts as vehicles to obtain certain particular aesthetic sensations or experiences[1]. On the one hand, literary appreciation is a necessary part of the aesthetic art that serves to purify human souls, and on the other hand, literary appreciation is a routine necessity to enlighten human spirits and improve human tastes of life[2]. G. Hegel (1770-1831) ever considered literary appreciation as a channel to get access to the "holy" and "pleasurable" satisfaction, thus making it full of philosophical meanings[3]. Meanwhile, Chinese scholars like Zhu Guangqian(1897-1986) and Li Zehou(1930- ) hold that literary appreciation will imply a potential motivation that may bring unexpected influences upon human minds and has historically become a holy career fulfilled by Chinese intellectuals in the past[1,4]. Accordingly, literary appreciation should be an important teaching activity in both universities and middle schools of China today. However, a field research about the rural middle schools and primary schools of Northern Shaanxi of China in 2010 makes us lost in thought. Wang Shudong, the author of the research, reports in his investigation that "the middle schools of Zhaoshipan Town" as well as "the primary schools in Baijialiang Village, Hemapan Village, Fengxishan Village, Daping Village and Fengshipan Village" are being deserted though they have been well-rebuilt because a large number of students are swarming into cities with their parents who hunt for jobs and make their own education impossible in the rural areas[5]. The middle schools and primary schools have these unpleasant tendencies, let alone the Senior High Schools of the local place. Then how about the literary appreciation in the lingering Senior High Schools of the local place? How about the literary appreciation in other Senior High Schools of Northern Shaanxi of China? How about the literary appreciation in all rural Senior High Schools of Shaanxi Province? How about the literary appreciation in all rural Senior High Schools of China? These questions make us restless. Making use of the opportunities of the students who accept teaching training practice in Junior or Senior Middle Schools of various places in Shaanxi Province, we make corresponding surveys in some typical rural Senior 
High Schools like Yehu Senior High School in Lantian County, The First Senior High School in Zhouzhi County, The Third Senior High School in Huxian County, The First Middle School in Gaolin County, etc., and we find that the situation about literary appreciation in rural Senior High Schools is really poor but not as poor as what we had imagined. Some rural Senior High Schools like Yanchuan Middle School in Yanchuan County, Meixian Middle School in Meixian County and Fuxian Senior High School in Fuxian County have very good reputation for their education quality and the number of the students there is fairly good. Besides, the schools have tried to fulfill literary appreciation in English classes though not successful to some degree. So we naturally think of the political environments of implementing literary appreciation into Chinese rural Senior High Schools, has our government had any good policies of changing the situation like that above? If the answer is Yes, what are the good policies to guarantee the smooth conduction of literary appreciation into the rural Senior High Schools?

\section{POLITICAL ENVIRONMENTS OF IMPLEMENTING LITERARY APPRECIATION INTO CHINESE RURAL SENIOR HIGH SCHOOLS}

\section{A. Receiving Quality-oriented Education Is Both Students' Rights and Their Obligations}

We have to admit that the overall environment of implementing literary appreciation in urban areas is much better than that in rural areas because Chinese rural areas are comparatively underdeveloped and the rural Senior High Schools may be not conscious enough of the necessity of literary appreciation in class while pursuing students' enrollment rate of universities and colleges as their goals. However, the issuing of The Educational Law of the PRC(1995) provides a legal background for both urban and rural Senior High Schools to fulfill quality-oriented education, which also creates the legal opportunities and fine atmosphere to implement literary appreciation into Chinese rural Senior High Schools. The Educational Law first proclaims that "The whole nation shall practice a system of nine-year compulsory education so national governments of all levels shall take effective measures to guarantee the school-age children or adolescents to go to school," which shows that all children in urban and rural areas have the same rights to receive education and learn the basic knowledge of life. Of course, this law also paves the foundation for those who go to Senior High Schools for all-around education. Rural Senior High Schools are no exception. Meanwhile, "receiving quality-oriented education is both students' rights and their obligations," and students are asked to "develop themselves in ethnics, intelligence, physique, etc. and establish themselves with high aspiration, morality, education and discipline,"[6] which implies that implementing literary appreciation into Chinese rural Senior High Schools will be necessary because as we have analyzed above, literary appreciation is an important teaching activity in school for the sake of quality-oriented education. According to The Decision of Deepening Chinese Education Reform and Promoting Comprehensively the Quality-oriented Education by the CPC Central Committee and the State Council(1999), literary appreciation is a reflection of national quality-oriented education that requires students' all-round development, both mentally and physically[7]. The document points out that "Comprehensively promoting our national quality-oriented education aims at fostering the national talents to meet the fundamental needs of socialist modernization and is oriented to the 21 st century." "Fulfilling our national quality-oriented education...is to cultivate students' spirits of innovation and abilities of practice to make them become the innovative and enterprising talents,"'[7] which requires all students to integrate Moral Education, Emotion Education, Physical Education and Art Education together for their comprehensive development. Then what about the role of literary appreciation in this policy? Specifically, literary appreciation is an organic component of Art Education and closely relates to Emotion Education and eventually does good to Moral Education and Physical Education, lying in the fact that literary appreciation "not only associates students' artistic attainments but also influences their aesthetic judgments", thus playing an irreplaceable role in developing their capabilities. Obviously, it seems significant to "involve literary appreciation into the whole procedure of school education" for students of different stages[6]. Moreover, Law of Compulsory Education of the PRC(2006) again emphasizes that all schools "must carry out the national educational policies, implement the quality-oriented education in reality, and accordingly improve our national educational levels."[8] At the same time, "governments at or above the county level shall provide support for the educational development of the local place, distribute educational resources rationally, and think out ways to improve the facilities of the weak schools," thus promoting "the balanced development of compulsory education" with the concern of all social forces. To some extent, rural compulsory education has been widely concentrated by the whole society, which provides a good stage for the rural Senior High Schools to implement literary appreciation, one way or another[8].

\section{B. The Rural Education Is One of the Fatal Projects of Revitalizing China in the Long Run}

Chinese Educational Revitalization Action Plan for the 21st Century(1998) announces that it is fairly essential to "make comprehensive reforms of agriculture, science and education through integrating all related educational sources" as well as "make full use of the role of rural education in national rural modernization."[9] The important reason is that the rural education is one of the fatal projects of revitalizing China in the long run. Rural education concerns the general education, adult education and professional education and takes the Senior High School education as one of the key focuses. While in the teaching procedures, the rural Senior High Schools have to highlight Art Education and pay attention to the function of literary appreciation in class because "Art Education is important to quality-oriented education....and does good to the potential talents of students." $[8,9]$ "Practicing the strategy of revitalizing China through science and education" and "constructing the life-long study system" will be the appealing measures to change the poor situations of the rural education and surely influence the effects of fulfilling literary appreciation in the rural Senior High Schools. However, it is also significant to "ensure the number and quality of teachers in school" and "improve their teaching standards", thus we must 
change the idea of "treating the educational investment as consumption investment" and we will have to "take the development of education as an important part of the national fundamental investment"[9], which may unexpectedly create good motivations for teachers to implement literary appreciation in class. Besides, to make literary appreciation go smoothly in rural Senior High Schools, "teachers should treat students equally...pay attention to their individual differences, teach them in accordance of their aptitude and stimulate them to develop fully," "teachers should respect students' personality, neither discriminating against them nor violating their dignity through any form of physical punishment or the similar improper behaviors"[7]. Definitely, improving the qualities of teachers is one of the crucial details of guaranteeing the peacefulness of carrying out the rural education and promising a good end of fulfilling literary appreciation in school, hence the General Office of CCCPC (1999) declares that "constructing a group of teachers with high qualities is the fundamental job of advancing the quality-oriented education among students" so we should focus on "teachers' capabilities and improve their teaching levels for students" $[7,9]$.

\section{Colorful and Diversified Course Designing Is Demanded in National Educational Reform and Development}

It is a fact that Shaanxi Province is one of the major provinces of education in China. Yet, compared with the eastern areas, Shaanxi Province still has much room to improve thus the fundamental reforms in education are required and the course designing needs corresponding changes. Actually, the colorful and diversified course designing is demanded in our national educational reform and development. The Decision on the Foundation Education Reform and Development of the State Council(2001) holds that "a new round of Chinese curriculum reform" is vital in the new era. It will be meaningful to "put forward the foundation education reform, adjust and modify the course systems, arrangements and contents to establish the new and more reasonable curriculum systems" for the sake of the changing society and the development of the world[10]. Surely, it is good for Chinese rural education and all rural Senior High Schools. We have to admit that in the past, the course designing concerned mainly about the knowledge absorbing and the teaching contents seem "difficult, complicated, partial and old" while the students were required to learn and memorize mechanically. The reform of the curriculum will "associate students' interests and experiences in study...inspire them to study actively," lead them to approach the essential teaching activities to "form their correct world outlook, views on life and values" $[9,10]$, which brings optimistic chances for rural Senior High School students to have literary appreciation in class. The document also advocates that colorful and diversified course designing aims to “explore students' abilities of finding problems, analyzing problems and solving problems on their own" as well as "develop their potential communicative and cooperative abilities with others."'[10] As for the regions like Shaanxi Province and the Senior High Schools in the rural areas, the document also points out that they should "grasp the precious opportunity of the west development of the nation, stimulate the overall advancement of the local education" with the help of "Compulsory Education Project for the National Poor
Areas" and "The Partner Assistance Project between the Eastern Areas and the Western Areas" $[8,9,10]$. To meet the basic demands of the colorful and diversified course designing, Ministry of Education furthers the detailed requirement, "the general Senior High Schools, besides satisfying the basic needs of teaching, should have various levels of choices for students who have potential learning desires and help them find more chances to develop themselves, which may pave the foundation for their surviving, operating and creating abilities" apart from the basic ability of literary appreciation in class. As we can observe, "the foundation education reform is a systematic project and its development needs a gradual process.'[9] In order to work out a reasonable course designing, it is advisable that the Senior High Schools should negotiate with the research institutions of various colleges and universities and make full use of both sides' advantages to reduce the risks of the unexpected consequences. At the same time, in order to have an effective fulfillment of literary appreciation in class, the Senior High School teachers "should have the scientific reflection of their own teaching behaviors through the evaluation systems that principals, other staff members, students and students' parents participate jointly' $[8,10]$.

\section{The Rural Senior High Schools Are Available to Improve the Populace's Cultivation}

The Curriculum Scheme for the Senior High Schools (experimental manuscript)(2003) claims that "the Senior High School education is the foundation education based upon the nine-year compulsory education and aims to improve the populace's cultivation, thus open to the public.'[11] Besides, the Senior High Schools are also the places available for students' lifelong development, so literary appreciation, a necessary part of students' lifelong career, should be considered much. As far as The Decision on the Foundation Education Reform and Development of the State Council(2001) is concerned, the rural Senior High Schools should develop themselves through referring to the realities of the local rural construction and development, and at the same time, they also take the responsibility of adhering to the educational objectives proposed by Ministry of Education to cultivate students of the local places into those "with strong physique, indomitable will, healthy lifestyle as well as good aesthetic tastes"[10]. Hence, literary appreciation in rural Senior High Schools seems politically meaningful. Moreover, the fulfillment of literary appreciation in rural Senior High Schools helps students "perfect their personality, strengthen their mind and boost their morale" and has the function of "knowing themselves and respecting others" while "establishing their professional consciousness, enterprising spirits and independent capabilities"[11]. To achieve these goals, The Decision(2001) emphasizes that the Senior High Schools should "satisfy the demands of the modern society" and "provide diverse standards of personnel training" through educating the talents of various fields. In this case, literary appreciation has to be involved in the routine classes of the Senior High Schools, including those in the rural areas. Additionally, we have to realize that the rural Senior High Schools should be the places where students could "comprehensively employ the acquired knowledge and experiences to cope with the problems appearing in their own life" and "cultivating the potential humanistic spirits and 
scientific literacy"[10]. Therefore, the existence of the rural Senior High Schools should also exemplify the characteristics of modernity, fundamentality and progressiveness, by viewing that literary appreciation has to be integrated into the teaching activities. To make sure all procedures working smoothly when fulfilling literary appreciation in class, Rao Yangbing concludes his proposals and claims that "three factors have to be cooperated," i.e., "first, a strong and united leadership;" "second, a high-quality faculty;" and "third, the necessary financial investment'[12].

\section{CONCLUSION}

In a word, literary appreciation is significant in Chinese rural Senior High Schools, lying in the fact that literary appreciation is necessary in the teaching procedures, which is not only an aesthetic art to purify students' souls, but also a routine necessity to enlighten students' spirits and improve their tastes of life. Considering the importance of literary appreciation in human life, both foreign philosophers and Chinese scholars value it privately. However, a field research about the rural middle schools and primary schools of Northern Shaanxi of China in 2010 makes us lost in thought. While feeling sorry for the poor conditions in the rural areas, we refer to our national laws and political documents to examine the political environments of implementing literary appreciation into Chinese rural Senior High Schools. We finally figure out that we should be optimistic about the future of literary appreciation in rural Senior High Schools. Specifically, since a lot of educational laws and political documents are available and play their roles in concrete fields and provide good environments for the development of the rural Senior High Schools as well as the fulfillment of literary appreciation in the rural Senior High Schools, we have confidence that Chinese rural Senior High Schools, together with the national rural education, will have a bright future. Meanwhile, fulfilling the literary appreciation in the rural Senior High Schools will be one of those rewarding experiences in our social life.

\section{ACKNOWLEDGMENT}

The research described in this paper is financially supported by the research programs sponsored by SNNU Elementary
Education Curriculum Research Center of Ministry of Education of China (JCJY201318); Shaanxi Social Science Association (2013Z092); the Innovation Funds of Graduate Programs (2013CXB013), SNNU; 2013 Visiting Scholar Exchange Program (P-1-04989), SNNU; Shaanxi Social Science Fund (08K005); and Ministry of Education of China (GPA105004, 10YJA752031).

\section{REFERENCES}

G. Q. Zhu, Of Beauty. Hefei: Anhui Education Press, 1997, pp. 9-12, 14. S. C. Liu, Fundamental Principles of Aesthetics. Shanghai: Shanghai People's Publishing House, 1999.

[3] G. Hegel, Aesthetics, vol. 3, book 1, G. Q. Zhu, Trans. Beijing: The Commercial Press, 1997, pp. 3-12.

[4] Z. H. Li, The Chinese Traditional Aesthetics. Tianjin: Tianjin Academy of Social Sciences, 2001, pp. 9-15.

[5] S. D. Wang, "Realities and reflections of the rural middle school and primary school education of Northern Shaanxi Province," http://www.bjwlxy.cn/_info/new_info/info_news_13593.htm, 2010-1026.

[6] The Educational Law of the PRC. http://www.lawlib.com/law/law_view.asp?id=11220, 1995-3-18.

[7] General Office of the CPC Central Committee, "The Decision of Deepening Chinese Education Reform and Promoting Comprehensively the Quality-oriented Education by the CPC Central Committee and the State Council,"

http://www.chinalawedu.com/news/1200/22598/22615/22793/2006/3/he7 396032197360029150-0.htm, 1999-6-13.

[8] Law of Compulsory Education of the PRC. http://www.npc.gov.cn/cwh/common/zw.jsp?label=WXZLK\&id=35017 8\&pdmc=fywj, 2006-6-29.

[9] Chinese Educational Revitalization Action Plan for the 21st Century. http://gov.hnedu.cn/web/0/200808/29112413281.html, 1998-12-24.

[10] The Decision on the Foundation Education Reform and Development of the State Council.

http://baike.baidu.com/link?url=Gij0esd_cTkUHS1tYJThbpc0z0DAGL-_Jt35Qiq5XG7nonBId0Izv6j6hBzQfZC7jlmnB1CKN1GzYjc QUUwYq, 2001-5-29.

[11] The Curriculum Scheme for the Senior High Schools (experimental manuscript). http://2.jxjjx.com/html/200812/101.html, 2003-3-31.

[12] Y.B. Rao, "Three basic factors to improve our education and teaching qualities,"

http://www.360doc.com/content/11/0505/20/6360242_114636758.shtml, 2008-12-26. 